\title{
Bailiffs' Training Needs Analysis for Supporting The Digitalization of Judicial Processes in Indonesia in The Pandemic Era
}

\author{
Zulfia Hanum Alfi Syahr ${ }^{1}$, Muhamad Zaky Albana ${ }^{2}$ \\ Law and Justice Research and Development Center the Supreme Court of the Republic of \\ Indonesia, Jalan Jend. Ahmad Yani Kav.58 bypass Cempaka Putih, Jakarta Pusat ${ }^{1,2}$
}

\{qvia.alfisyahr@gmail.com¹, zakyalbana@gmail.com²\}

\begin{abstract}
Bailiffs are part of the judicial apparatus who have the task of executing decisions. The execution is vital to enforce the law for people who seek justice; however, during the Covid-19 pandemic, many executions must be delayed and switched by implementing virtual applications. Bailiffs faced many problems in adapting to a virtual task since there is no training to use these judicial applications. This paper's focussed issue is training needs analysis for bailiffs to do execution in the current pandemic era. The goal is to improve the competence of bailiffs as judicial apparatus. The method used was quantitative using a survey distributed to bailiffs in general, religion and state administrative court. The result was that bailiffs needed the training to improve their competence, especially using court applications and psychological and mass negotiation skills.
\end{abstract}

Keywords: Bailiffs; Competence; Training Needs Analysis

\section{Introduction}

Law Number 48 of 2009 on Judicial Power states that bailiffs are "judicial officials". The existence of bailiffs as judicial officials is scattered throughout the general, religious and administrative courts all around Indonesia. Bailiffs, as court officers have duties in the trial process to assist judges and outside the court to carry out court orders and executions [1]. The function of bailiffs is to execute court decisions that have legal force. Bailiffs play a role in carrying out the stages in the civil execution process to run smoothly and effectively [2]. Seeing the role of bailiffs in the execution process, so far, the guidance of bailiffs as a resource for the judicial apparatus has not been implemented optimally. There is no continuing education and training program to increase bailiffs' capacity in carrying out their duties. The current bailiff's training program is limited to technical directions and instructions from the court's clerk and the head of the court. Of course, this is very insufficient to support efforts to improve bailiffs' quality in realizing law enforcement for the justice-seeking community.

Especially during the current pandemic, the legal process has switched from offline to virtual by implementing various judicial applications. Transitioning the judicial process from offline to online has advantages and disadvantages. The advantage is that the public's access to 
court is more comprehensive without being constrained by distance and time. The disadvantage is that it is challenging to manage interactions between victims, defendants, and judges in the virtual trial process [3]. The task of bailiffs as executor also encountered problems with the transition of tasks to virtual ones because many forced execution processes had to be delayed due to the Covid-19 outbreak that hit Indonesia at this time. Based on the Supreme Court Circular Letter Number 1 of 2020, judicial administration's implementation is carried out using E-court [4]. Some of the duties of bailiffs in courts that have begun to be carried out online, for example, are court summons, which was previously carried out in person, now using the e-summon application which is also integrated with e-Court. This summons is one of the essential elements in the case examination system because if there is negligence in the summons' execution, it will cause defects in the case examination process [5]. One of these is why it is crucial to increase bailiffs' ability to use various judicial applications.

Besides, the importance of strengthening the human resources of bailiffs in court is in line with Government Regulation Number 11 of 2017 concerning State Civil Apparatus Management Article 203 paragraph 4 which states that for civil servant competency development it takes 20 (twenty) lesson hours a year. This regulation shows that the government has encouraged current civil servants' competency development through training and seminar programs. The current civil servant's management bureaucratic reform has also led to the functionalization of employees. Bureaucratic reform supports the realization of good governance, which is the main element in improving the conditions for national and state life [6]. So far, the public considers that bureaucracy is a complicated, slow and expensive procedure [7]. Therefore, to form a good image of the bureaucracy in government agencies, the government supports each agency to have the opportunity to propose various nomenclature of positions that can fall into the category of functional positions. The purpose of this civil servant functionalization is to improve professionalism and competence for each position holder. A civil servant can have independence in a broader opportunity to improve his competence through various technical training that supports his / her job duties through a functional position.

In this case, bailiffs as one of the nomenclature of civil servant positions who have an essential function in carrying out the court's primary duties as a government agency are very appropriate if they can be proposed as functional nomenclature in civil servant. Efforts to realize bailiffs as functional nomenclature need to be supported by identifying what competencies are needed to adjust job demands based on technological developments and legal issues in society. Identification of bailiffs' competency as functional nomenclature can be carried out using the training needs analysis method. This bailiff's training needs analysis will explore what competencies are required for the training program to be carried out and what kind of training methods can be carried out following the characteristics of the bailiff's job in court. Of course, increasing the competence of bailiffs from the results of the training needs analysis will support to build of a judicial institution that is transparent, accountable and free from collusion, corruption and nepotism.

\section{Method}

The research method used in this paper is a quantitative research using a training needs analysis survey. The primary data obtained were analyzed with descriptive statistics. Statistical analysis is used to process data on the percentage of survey results. Descriptive 
analysis is used to explain the survey results about the research object. The research data is supported by secondary data in the form of relevant references, both books and journals, and various related regulations. The survey of bailiffs' training needs analysis was distributed to 266 bailiffs as respondents from courts all around Indonesia. The survey was conducted in October-November 2020.

\section{Discussion}

\subsection{Digitalization of the Judicial Process}

The Supreme Court of the Republic of Indonesia as one of the holders of judicial power in Indonesia has the aim of having information management that ensures accountability, credibility and transparency as well as becoming a modern, integrated information and technology-based organization [8]. The digitization of the judicial process in Indonesia begins with the use of the Case Tracking Information System (CTS) as well known as "Sistem Informasi Penelusuran Perkara" (SIPP) which was inaugurated on March 23, 2011 at the Palembang District Court. The basic function of the SIPP is directly related to the collection, storage, processing and presentation of case administration information in court. The basic function of the SIPP is primarily aimed at providing services to court parties and litigant parties to find out about the progress of case handling, while the advanced functions of SIPP are used, among other things, to fulfill the interests of court management in decision making, activity planning and budgeting interests as well as research and development interests. [9]. It can be said that using the SIPP application is the first step in digitizing the judicial process in Indonesia.

The development of digitalization of the judicial process in Indonesia cannot be separated from the application of the electronic trial system (E-court) which was launched by the Supreme Court of the Republic of Indonesia on July 13, 2018 in Balikpapan. The issuance of Supreme Court Regulation Number 3 of 2018 concerning Case Administration in the Court Electronically which was later revised by the Regulation of the Supreme Court of the Republic of Indonesia Number 1 of 2019 concerning Electronic Case Administration and Trials in Courts marks a new chapter of the trial process in Indonesia which carries a simple principle, fast and low cost. The e-court application is a series of processes for accepting claims or requests, answers, replications, duplicates, and conclusions, management, submission and storage of case documents using an electronic system applicable in each court environment [10]. The birth of the e-Court is an innovation as well as a commitment for the Supreme Court of the Republic of Indonesia in realizing reforms in the Indonesian judiciary (Justice reform) which synergizes the role of information technology (IT) with procedural law (IT for Judiciary) [11]. The role of e-court in court is increasingly needed, especially since 2020 Indonesia was hit by the Covid-19 pandemic, which forced some daily activities, including trials, to be carried out virtually.

By definition, e-court is an instrument of the Court as a form of service to the public in terms of online case registration, electronic cost estimation, online payment of fees, online summons and online trials as well as sending court documents (replicates, duplicates, conclusion, answer) [12]. Based on the definition, e-court is used for online trials in civil, religious, military and state administration cases. As for criminal cases, the Supreme Court of the Republic of Indonesia issued Supreme Court Regulation Number 4 of 2020 concerning the Administration and Trial of Criminal Cases in Electronic Courts. At trial in criminal cases, the 
defendant can be presented virtually and pronounce the verdict and notification of the verdict electronically.

The type of service in the e-court that intersects with bailiff's duties is parties summoning service through the e-summon application. Through the e-summon application, court summons and notification of decisions are conveyed to the parties via electronic channels to the parties' email addresses and information on the summons can be seen on the e-court application. Currently, notifications via e-summon are addressed to the electronic domicile of the plaintiff that has registered electronically. Whereas for the defendant, the first summons is done manually and when the defendant is present at the first trial, approval will be asked whether to agree to the summons electronically or not, if agreed, the defendant will be summoned electronically in accordance with the electronic domicile given and if not done manually as usual [12]. In accordance with Article 16 of the Supreme Court Regulation of the Republic of Indonesia Number 1 of 2019 concerning the Administration of Cases and Trials at Courts, the task of bailiffs is to send a summons to the court to the parties' electronic domicile through the court information system. In addition, bailiffs must also continue to monitor the case process through the court information system until the judge's decision stage, related to the delivery of court documents (replicates, duplicates, conclusions, answers), handling of electronic evidence and updates to the Case Tracking Information System application or SIPP.

Thus, the increased duties and responsibilities of bailiffs have an impact on the need for technical competencies related to information systems and technology that have been implemented by the court. The digitalization of the judicial process requires judicial officials including bailiffs to develop and acquire knowledge about information technology which is also growing. Based on the survey results, until 2020 there has not been any education and training on information systems and technology for bailiffs. Therefore, it is necessary to develop the capability and competence of bailiffs in information technology through education and training conducted by the Supreme Court.

\subsection{Training Needs Analysis for Bailiffs}

Human resource development as human capital can be seen in several ways which emphasize the core competence, capability, and the learning process [13]. Efforts to develop human resources so that they can play a role in the growth and change of an organization can be carried out by organizing education and training programs [14]. The ability of bailiffs as part of judicial human resources to be able to fulfill the three elements of human capital can be done by using training needs analysis. Analysis of training needs can assist organizations in maximizing their resources to meet what training participants need most [15]. Bailiff's training needs analysis is carried out based on the bailiff's job in court. The main duties of bailiffs can be carried out well if each of the occupants has mastered certain required competencies. Certain competencies that bailiffs need and have a role in supporting the main functions of the court are known as technical competencies. These technical competency needs are then developed through an analysis of training needs to become a continuous education and training program for bailiffs in the general, religion and state administration court. The education and training needs analysis survey has been distributed to bailiffs from general, religion and state administration courts all around Indonesia. The need for bailiff training based on the survey results can be seen in table 1 below. 
Table 1. Bailiff' Training Needs Analysis

\begin{tabular}{clcc}
\hline Number & \multicolumn{1}{c}{ Training Needs } & Respondents & Percentage \\
\hline 1. & Negotiation Training & 179 & $67 \%$ \\
2. & Bailiff's Functional Training & 166 & $62 \%$ \\
3. & Psychology Communication Training & 154 & $58 \%$ \\
4. & Self Defense Training & 124 & $47 \%$ \\
5. & Substitute Bailiff' Functional Training & 111 & $42 \%$ \\
6. & Judicial Technology Information System Training & 61 & $23 \%$ \\
7. & Judicial Technology Information Development Training & 47 & $18 \%$ \\
8. & Case Management Training & 21 & $8 \%$ \\
9. & Electronic Evidence Handling Training & 10 & $4 \%$ \\
10. & Small Claim Court Training & 8 & $3 \%$ \\
\hline
\end{tabular}

Source: Processed Data (2020)

Table 1 above shows the 10 (ten) types of training that are most needed by bailiffs. The training program that was most in demand was the negotiation training program selected by 179 respondents. Negotiation skills are important for bailiffs to have because they are related to their job duties, which must deal directly with the parties in a case. Where the bailiff must be able to make the parties involved understand to implement court decisions. In this process, bailiffs often experience obstacles in the form of verbal to physical expulsion. This risk causes bailiffs to be equipped with capable negotiation skills to be able to make the losing party comply with court decisions. This can be realized by opening a negotiation training program for bailiffs that has never existed.

In the second position, there was a bailiff's functional training program selected by 166 respondents. Bailiff's functional training is very important to be a requirement for an employee who wants to occupy the position of bailiff. Bailiff's functional training will provide basic learning about the main tasks of a bailiff in terms of field practice and in the office. The third training program needed is psychology communication training to understand the various characters of the litigants. Psychology communication training is closely related to negotiation training, because the ability to understand various character can support the negotiation process safely and peacefully. In carrying out his duties, the bailiff must face the losing party in the case. Of course, dealing with this losing party requires a special strategy to understand the character of each individual so that bailiffs can find appropriate and safe negotiation steps, so that court decisions can be carried out.

Another education and training program that is very important in the effort to adapt the digitalization of judicial process during this pandemic is Judicial Technology Information System implementation and development training. Bailiffs, who have mostly worked in the field to deal with the parties, now have to go online in an effort to implement health protocols during this pandemic. The training program for the application and development of judicial information systems is very necessary to be implemented, with the aim of being able to develop existing judicial applications, namely e-court. The e-court has integrated e-litigation, e-filling, e-skum and e-summon. Through the judicial information system training program, it is hoped that e-court can be developed so that it can be used for online dispute resolution. Online dispute resolution services include case management, evidence submission, to mediation and negotiation processes [16]. The realization of online dispute resolution will increase the role of bailiffs in carrying out bailiff's duties related to online civil dispute resolution. Thus, bailiffs need to improve their abilities so that they can familiarize themselves with the use of judicial applications through appropriate education and training programs. 


\section{Conclusion}

Based on the explanation above, guidance for bailiffs as judicial officers has not been carried out optimally. The Supreme Court does not yet have a special, sustainable training program to increase the capacity of bailiffs. Bailiffs have an important role in the execution of court decisions. The bailiff must face the parties in a case and must be able to provide understanding to the parties to comply with court orders and decisions that have legal force. In addition, the application of digital technology in the judicial process, especially during the current pandemic, must be carried out properly by bailiffs so that the case handling process can continue to run well. The Supreme Court has implemented an e-court application to facilitate justice seekers in this pandemic to continue to receive court services virtually without having to come to court. During the Covid-19 pandemic, bailiffs had to get used to switching from field assignments to virtual ones using e-court. Of course, to support the bailiff's ability to implement a digital information system via e-court, it is necessary to develop a training program according to the needs of bailiffs. The results of the training needs analysis survey show that the competence of bailiffs that really needs to be improved is in terms of negotiation skills, understanding of communication psychology and mastery of implementing and developing judicial information systems.

\section{Acknowledgement}

We would like to express our gratitude to Law and Justice Research and Development Center, Supreme Court of the Republic of Indonesia for supporting this research activity. Further on we have to thank Sri Gilang M. Sultan Rahma Putra for developing this research instruments, as well as Izarre Hanania Pratama and Adzkiya Azura Albana for providing support on article preparation.

\section{References}

[1] T. M. Dunlap, "People You Should Know The Bailiffs and Court Marshals," J. Mo. Bar, no. May-June, pp. 134-138, 2014.

[2] A. D. Ma Ina Puraveli, "Bailiff Office in Albania and Changes in the Form of Organization , Under the Administrative and Implementing Reforms in Law," Mediterr. J. Soc. Sci., vol. 3, no. April, pp. 23-28, 2012.

[3] J. M. Baldwin, J. M. Eassey, and E. J. Brooke, "Court Operations during the COVID19 Pandemic,” Am. J. Crim. Justice, vol. 45, no. 4, pp. 743-758, 2020.

[4] H. P. Arifin, A. Ferdian, M. Djunaedi, and D. I. Agustina, "E-Court Implementation In Civil Cities Jurisdiction In The Covid-19 Pandemic Time," Yurisdiksi J. Wacana Huk. dan Sains, vol. 17, no. 2, pp. 97-107, 2020.

[5] M. Y. H. Dian Puspita, Osgar S. Matompo, "Peranan Juru Sita Pengganti Dalam Pelaksanaan Tugas Pokok dan Fungsi Peradilan Tata Usaha Negara (Studi Pada Pengadilan Tata Usaha Negara Palu)," J. Kolaboratif Sains, vol. 1, no. 1, pp. 1720 1732, 2019.

[6] M. Ibrahim, "Reformasi Birokrasi Pada Lingkungan Peradilan Agama di Indonesia," Al-Ahwal, vol. 11, no. 2, pp. 133-146, 2018.

[7] T. Sudrajat, "Gagasan tentang Fungsionalisasi Jabatan dalam rangka Reformasi Birokrasi,” J. Kebijak. dan Manaj. PNS, vol. 7, no. 1, 2013. 
[8] Mahkamah Agung RI, Cetak biru pembaruan peradilan 2010-2035. Jakarta: Mahkamah Agung RI, 2010.

[9] M. A. RI, Roadmap Rencana Pengembangan Sistem Penelusuran Informasi Perkara Mahkamah Agung Republik Indonesia Tahun 2015-2019. 2015.

[10] S. Retnaningsih, D. L. S. Nasution, R. A. Velentina, and K. Manthovani, "Pelaksanaan E-Court Menurut Perma Nomor 3 Tahun 2018 Tentang Administrasi Perkara Di Pengadilan Secara Elektronik Dan E-Litigation Menurut Perma Nomor 1 Tahun 2019 Tentang Administrasi Perkara Dan Persidangan Di Pengadilan Secara Elektronik (Studi Di Pengadilan Negeri Di Indonesia)," J. Huk. Pembang., vol. 50, no. 1, p. 124, 2020.

[11] I. Atikah, "Implementasi E-Court dan Dampaknya Terhadap Advokat Dalam Proses Penyelesaian Perkara di Indonesia," in Social and Political Chalenges in Industrial 4.0, 2018, p. 125.

[12] Mahkamah Agung RI, Buku Panduan e-Court "The Electronic Justice System. 2019.

[13] A. Rakhmawanto, "Membangun Model Pengembangan SDM Aparatur Pegawai Negeri Sipil," J. Kebijak. dan Manaj. PNS, vol. 2, no. 1, pp. 97-121, 2008.

[14] Suhanda, "Urgensi Sumber Daya Manusia Menuju Aparatur Sipil Negara Potensial Berbasis Ketangguhan Mental Spiritual," Ri'ayah, vol. 1, no. 2, pp. 206-220, 2016.

[15] A. Bansal and J. Prakash Tripathi, "A Literature Review on Training Need Analysis," IOSR J. Bus. Manag. (IOSR-JBM, vol. 19, no. 10, pp. 50-56, 2017.

[16] J. McIntyre, A. Olijnyk, and K. Pender, "Civil Courts and COVID-19: Challenge and Opportunities in Australia," Altern. Law J., vol. 45, no. 3, pp. 195-201, 2020. 